JOLANTA BONAR

Uniwersytet Łódzki

\title{
Rozpoznawanie i wspieranie kreatywności uczniów zadaniem nauczyciela wczesnej edukacji
}

Twórczość jest najwyższą formą działania wśród ludzi i dla ludzi. Możliwością takiego życia, w którym człowiek oddaje swe siły wartościom obiektywnym, a jednocześnie urzeczywistnia samego siebie ${ }^{1}$. Michał Kleiber, prezes Polskiej Akademii Nauk, doceniając wartość twórczości dodaje bardziej pragmatyczne uzasadnienie konieczności jej rozwijania. Podkreśla, iż w dzisiejszym zglobalizowanym świecie trwa rywalizacja, która będzie miała niezwykle silne konsekwencje dla nas wszystkich, a szczególnie młodego pokolenia. Musimy mieć świadomość, że wschodzące giganty, takie kraje jak Chiny, Indie czy Brazylia, są w stanie produkować wszystko i na dodatek robić to bardzo tanio. Jeśli więc chcemy mieć taką przyszłość do jakiej aspirujemy - i do jakiej mamy prawo aspirować - to nie ma wątpliwości, że powinniśmy stawiać na twórcze zachowania ludzi, organizacji, przedsiębiorstw. Jest to jedyna szansa dla kraju, który jest częścią starej Europy, członkiem Unii Europejskiej, zachodniej kultury $^{2}$. Konieczność wspierania postawy twórczej jest coraz wyraźniej dostrzegana również w świadomości społecznej Polaków. Badania porównawcze służące określeniu poziomu uznania dla kreatywności pokazały, iż Polska uzyskała wynik zbliżony do Stanów Zjednoczonych i znajduje się na siódmym miejscu wśród 16 badanych państw. 69\% Polaków uznaje samodzielne myślenie za ważniejsze w przygotowaniu do życia, 25\% wyżej ceni posłuszeństwo, a $6 \%$ nie ma zdania na ten temat. Oznacza to, e siedmiu na dziesięciu Polaków chciałoby mieć dzieci kreatywne, a co czwarty - konformistyczne. Warto również dodać, ze kreatywność bardziej cenią mieszkańcy dużych miast oraz ludzie młodzi. Największy szacunek dla tej cechy występuje w Norwegii i Niemczech (92\% Norwegów uważa, iż samodzielność myślenia jest ważniejsza w przygotowaniu do życia, a 6\% wyżej ceni posłuszeństwo), nieco mniejszy w Czechach i Austrii, zaś najniższy w Hiszpanii, Włoszech, Holandii i na

\footnotetext{
${ }^{1}$ W. Tatarkiewicz, Dzieje sześciu pojęć, Warszawa 1982.

${ }^{2}$ M. Kleiber, Czy współczesny człowiek skazany jest na twórczość?, „Meritum” 2008, nr 3.
} 
Węgrzech (41\% Hiszpanów wyżej ceni samodzielne myślenie, a 49\% posłuszeństwo $)^{3}$.

Kreatywność powinna być pojęciem bardzo silnie artykułowanym na wszystkich poziomach edukacji. Wszystkie programy, wszystkie pomysły na realizację tych programów powinny uwzględniać na pierwszym miejscu fakt konieczności rozwijania kreatywności u młodych osób ${ }^{4}$. Szczególnie ważne są pierwsze lata edukacji. To od nich bowiem w znacznym stopniu zależy, kim w sensie osobowościowym i intelektualnym będą nasi wychowankowie, jakie strategie myślenia będą mieli ukształtowane, a jakich - co może jeszcze bardziej istotne - posiadać nie będą . Stąd zapewne w podstawie programowej kształcenia ogólnego dla szkół podstawowych, w zadaniach przewidzianych do realizacji na poziomie edukacji wczesnoszkolnej znajduje się zapis wskazujący na konieczność zapewnienia dziecku przyjaznych, bezpiecznych i zdrowych warunków do nauki i zabawy, działania indywidualnego i zespołowego, rozwijania samodzielności oraz odpowiedzialności za siebie i najbliższe otoczenie, ekspresji plastycznej, muzycznej i ruchowej, aktywności badawczej, a także działalności twórczej.

\section{Twórczość dziecięca}

Do najbardziej znanych propagatorów twórczości dziecięcej należą Robert Gloton i Claude Clero. Twierdzą oni, iż dziecko w sposób naturalny jest twórcą. Aktywność dziecka należy do sfery rozwoju i jest catkowicie zwrócona w kierunku budowania siebie. Twórcza aktywność dziecka zyskuje sens biologiczny właśnie dzięki tej życiowej potrzebie wzrastania, catkowicie zwróconego ku przyszłości i będacego przekraczaniem samego siebie, [...] stanowi potrzebe biologiczna, której zaspokojenie jest absolutna koniecznościq dla optymalnego rozwoju istoty ludzkiej w okresie wzrostu ${ }^{6}$.

Również Teresa Amabile uznaje istnienie twórczości dziecięcej. Twierdzi, że wszystko co dziecko myśli lub robi może być uznane za twórcze jeśli spełnia dwa warunki. Musi być rzeczywiście odmienne od wszystkiego, co dziecko do tej pory zrobiło, widziało i słyszało, ale jednocześnie poprawne, użyteczne dla osiaggnięcia celu, atrakcyjne bądź znaczące dla dziecka w pewien sposób. Twórcze zachowania dziecka muszą być zatem uznane za nowe i użyteczne, nie

\footnotetext{
${ }^{3}$ M. Karwowski, Dzieci kreatywne, czy konformistyczne?, [w:] Kreatywność - nowe aspekty poznawcze i praktyczne, pod red. W. Dobrołowicz, J. Gralewski, Warszawa 2005.

${ }^{4} \mathrm{M}$. Kleiber, Czy wspótczesny człowiek...

${ }^{5}$ D. Klus-Stańska, Polska wersja integracji treści w perspektywie teorii psychologicznych, czyli dlaczego ogórek nie śpiewa?, [w:] Zreformowana wczesna edukacja - od refleksji ku działaniom nauczyciela, pod red. M. Nowicka, Warszawa 2005.

${ }^{6}$ R. Gloton, C. Clero, Twórcza aktywność dziecka, Warszawa 1985, s. 57-58.
} 
mogą być imitacją tego, co dziecko widziało wcześniej, ale muszą być jednocześnie dostępne repertuarowi zachowań dziecięcych. Aby móc ocenić twórczość dzieci, potrzebne są wiadomości o jego wcześniejszych doświadczeniach i wiedzy. Trudniej jest natomiast stosować kryterium użyteczności, zwłaszcza w odniesieniu do dziecięcej sztuki, gry, fantazjowania czy tworzenia opowiadań. Jeśli nowe zachowanie dziecka jest komunikatywne, ma określone znaczenie lub jest źródłem dodatnich uczuć, przynajmniej dla dziecka, można uznać, ze jest stosowne i użyteczne. Podstawowa teza T. Amabile głosi, że każde dziecko jest zdolne do generowania twórczych wytworów w określonej dziedzinie, w pewnym określonym czasie ${ }^{7}$. Witold Dobrołowicz zauważa jednak, iż większym zainteresowaniem badaczy cieszy się twórczość artystyczna - zwłaszcza plastyczna i muzyczna - dzieci. Rzadziej natomiast analizowana jest twórczość poznawcza (naukowa, techniczna, organizacyjna), w której myślenie odgrywa większą rolę niż emocje ${ }^{8}$.

Jerzy Kujawiński uważa, iż twórczość dziecka ma charakter subiektywny, co oznacza, że efektem tej twórczości są przedmioty (wytwory, odkrycia, zachowania) nowe i pożyteczne dla samego twórczo działającego ucznia. Twórczość ta, podobnie jak twórczość obiektywna, nie opiera się na żadnych regułach działania. Jej celem i istotą jest wychodzenie poza posiadane informacje i tworzenie lub odkrywanie rzeczy nowych. Stworzona lub odkryta przez dziecko nowość jest rezultatem dokonanej przez nie syntezy różnych składników rzeczywistości. Istota procesu twórczego dziecka polega bowiem na reorganizowaniu jego dotychczasowego doświadczenia i tworzeniu lub odkrywaniu nowych i wartościowych dla niego przedmiotów teoretycznych (wiadomości, poglądów, ideałów, itp.) oraz fizycznych (technicznych, konstrukcyjnych, plastycznych, muzycznych, ruchowych itp. $)^{9}$

Krzysztof Szmidt zebrał liczne argumenty psychologów przemawiające za prawdziwością tezy o tym, że dzieci są twórcze. Wskazują oni, iż małe dzieci przejawiają wiele zachowań oryginalnych, dostosowanych do okoliczności, trafnie rozwiązujących problem. Twórcza ekspresja dzieci często ma charakter oryginalny i określone znaczenie dla samego dziecka, ale jej wytwory nie powinny być porównywane z ogólnymi standardami twórczości dojrzałej. Dzieci rysują, malują, układają wierszyki i piosenki, i chociaż ich wytwory nie noszą znamion wielkości, stanowią ważną przesłankę rozwoju w ogóle, a nie tylko rozwoju zdolności twórczych ${ }^{10}$. Twórczość sprawia dzieciom ogromną osobistą

${ }^{7}$ T. M. Amabile, Growing Up Creative: Nurturing a Lifetime of Creativity, C.E.F Press, The Creative Education foundation, Buffalo, New York 1992.

${ }^{8}$ W. Dobrolowicz, J. Dobrołowicz, Gdzie ekspert nie może ...Dzieci rozwiazuja poważne problemy, Kielce 2009.

${ }^{9}$ J. Kujawiński (red.), Rozwijanie aktywności twórczej uczniów klas początkowych, Warszawa 1990.

${ }^{10}$ K. J. Szmidt, Pedagogika twórczości, Gdańsk 2007. 
przyjemność i satysfakcję, jest źródłem zadowolenia przez co ma znaczny wpływ na rozwój ich osobowości. Towarzyszy zabawie, a więc ważnemu rodzajowi aktywności, uprzyjemnia ją, powoduje, że dzieci są szczęśliwe, co prowadzi do dobrego przystosowania psychicznego i społecznego ${ }^{11}$. Aktywność twórcza pełni zatem w życiu dziecka liczne funkcje. K. Szmidt zalicza do nich:

- funkcję rozwojową - twórczość pomaga rozwinąc się różnym sferom osobowości dziecka,

- funkcję ekspresyjną - twórczość umożliwia dzieciom wyrażanie indywidualnych myśli i przeżyć poprzez zabawę lub sztukę,

- funkcję socjalizacyjną - twórczość wdraża dzieci do odgrywania określonych ról społecznych i podejmowania wysiłku oraz odpowiedzialności za inne osoby,

- funkcję terapeutyczną - dzięki aktywności twórczej dzieci odreagowują nagromadzone napięcia i lęki, uczą się rozwiązywać konflikty w konstruktywny sposób,

- funkcję edukacyjną - twórczość dzieci sprzyja opanowaniu nowych umiejętności i wiedzy, wzbogaca proces nauczania i uczenia się o nowe treści i metody, zachęca do eksploracji oraz czerpania wiedzy z różnych źródet ${ }^{12}$.

Według Carla Rogersa aby człowiek mógł być twórczy, musi czuć się pod względem psychologicznym bezpieczny i wolny. Poczucie psychicznego bezpieczeństwa może wynikać z trzech wzajemnie powiązanych okoliczności:

1. bezwarunkowej akceptacji dziecka jako jednostki, której wartość i pokładana w nią wiara nie zależy od jej stanu w danym momencie,

2. unikania ocen zewnętrznych i zachęty do samooceny,

3. wczuwania się wychowawcy w sytuację dziecka i oglądania świata z jego perspektywy, rozumienie dziecka i przyjmowanie je, jakim jest ${ }^{13}$.

Wolność w sensie psychologicznym potrzebna jest po to, żeby nie krępować ekspresji dziecka. Dzieci powinny czuć się na tyle bezpiecznie, aby próbować nowych rozwiązań, powinny też cieszyć się wolnością poszukiwań. W twórczej atmosferze dorośli i dzieci cenią oryginalność, a nie konformizm, różnorodność, nie zaś uniformizację, eksperymentowanie, a nie asekurację ${ }^{14}$.

\section{Środowisko edukacyjne jako stymulator twórczości}

Przyjęcie założenia, iż twórczość daje się stymulować i rozwijać, nakłada również na środowiska edukacyjne obowiązek organizowania celowej działalno-

\footnotetext{
${ }^{11}$ Por. E. Hurlock, Rozwój dziecka, Warszawa 1985.

${ }^{12}$ K. J. Szmidt, Pedagogika..., s.177.

${ }^{13}$ C. R. Rogers $O$ stawaniu się sobq. Poglady na psychoterapię, Poznań 2002.

${ }^{14}$ R. Fischer, Uczymy jak myśleć, Warszawa 1999.
} 
ści wspierającej postawę twórczą wychowanków. Zadanie nie jest jednak łatwe. Przy projektowaniu wszelkich działań dydaktycznych, organizowanych zarówno w szkole jak i w domu, warto pamiętać o myśli Heleny Radlińskiej, iż za nikogo nie można się rozwijać, za nikogo - wzrastać. Można tylko pielęgnować wzrost przez usuwanie przeszkód, które go hamuja, i wyrównanie skrzywień. Można uprawiać glebę wzrastania, wzbogacając ją cennymi składnikami ${ }^{15}$. Aby stymulować rozwój młodego pokolenia, wspierać rozwój jego postawy twórczej potrzebne są dobre programy edukacyjne oraz profesjonalni wychowawcy. Zdaniem większości pedagogów i psychologów szkoły nie potrafią wywiązać się $\mathrm{z}$ tego zadania. Wprost przeciwnie uważają oni, że niekorzystne warunki szkolne mogą W znacznym stopniu neutralizować stymulowanie twórczości przez korzystne środowisko rodzinne. Nie bez powodu mówi się o tym, iż wiek podjęcia nauki szkolnej jest „, okresem krytycznym” w rozwoju twórczości.

Spośród wielu uwarunkowań szkolnych, które nie sprzyjają twórczości wymienia się: liczne klasy, w których niezbędna jest surowa dyscyplina, kładzenie nacisku na zapamiętywanie, zniechęcanie dzieci do wszystkiego, co nie jest zgodne z utartymi wzorcami, rygorystyczny rozkład zajęć szkolnych, przekonanie nauczycieli, że dzieci twórcze są trudne do kierowania, a ich pracę trudniej ocenić niż pracę konformistów. Jeżeli nauczyciele uważają, postępy w nauce za jedyną drogę do osiagnięcia sukcesu w życiu, wymienione przeszkody w ekspresji twórczej mogą okazać się bardzo poważne. Raporty z badań osiaggnięć szkolnych donoszą, iż wielu szkołom nie udaje się wzbudzić i rozwinać myślenia twórczego dzieci ${ }^{16}$. Dobre szkoły charakteryzują się wymagającym intelektualnie nauczaniem. Programy nauczania dla szkół podstawowych tworzone są głównie z uwzględnieniem potrzeb uczniów przeciętnych, natomiast dzieci uzdolnione i twórcze muszą dostosowywać się do poziomu średniego ${ }^{17}$.

Z podobną krytyką obecnej szkoły spotykamy się również w literaturze polskiej. Naukowcy wskazują liczne przeszkody utrudniające wyzwalanie i wspieranie postawy twórczej wychowanków. Edward Nęcka uważa, że szkoła częściej wpływa negatywnie niż pozytywnie na rozwój twórczości swoich wychowanków. Dzieje się tak dlatego, iż ujednolica ona zachowanie i sposób myślenia działając jak gdyby w zastępstwie całego społeczeństwa. Szkoła jest miejscem, w którym przekazuje się wiedzę, normy i wartości, ale także uczy konformizmu. Tutaj dziecko uczy się obowiązujących reguł zachowania, ale często także obowiązujących reguł myślenia. Uczy się na przykład, że pytania zadaje nauczyciel, a od ucznia oczekuje się jedynie odpowiedzi. Ponieważ najczęściej chodzi o jedyną, poprawną odpowiedź dodatkowo dzieci uczą się zachowań

${ }^{15}$ H. Radlińska, Oświata dorostych, Warszawa 1947, s. 20.

${ }^{16}$ R. Fischer, Uczymy jak myśleć, Warszawa 1999.

${ }^{17}$ F. J. Monks, Zdolności a twórczość, [w:] Teoria i praktyka edukacji uczniów zdolnych, pod red. W. Limont, Kraków 2004. 
„konwergencyjnych”, porzucając skłonność do dywergencyjnego wymyślania wielu alternatywnych rozwiązań. I choć dzieci w różnym stopniu podporządkowują się wymaganiom szkoły, z badań wynika, iż konformizmowi wobec reguł szkolnych towarzyszą niskie wyniki w testach twórczego myślenia. Pewien wpływ odgrywa tu też silna potrzeba wzorowania się na rówieśnikach. Zazwyczaj na dzieciach o wysokiej pozycji w grupie, nie zawsze jednak o wysokim poziomie myślenia twórczego ${ }^{18}$.

Szkoła nie sprzyja twórczości również ze względu na sposób przekazywania wiedzy. Próbuje przekazać jak najwięcej wiadomości nie dbając o stymulowanie myślenia, wyobraźni, dociekliwości i samodzielności intelektualnej. Wiedza szkolna nie sprzyja twórczości ponieważ: rzadko zawiera pytania; najczęściej ograniczając się do przekazywania twierdzeń; nie pokazuje perspektyw rozwojowych danej dyscypliny; jest mało impikatywna, to znaczy wynika z niej niewiele ponad to, co już jest w niej zawarte oraz operuje mało kreatywnym językiem, na przykład unika analogii, porównan i metafor, które są potężnym narzędziem twórczego myślenia.

Również Witold Dobrołowicz uważa, iż szkoła nie rozwija potencjału twórczego dzieci i młodzieży, a wręcz odwrotnie - mimo woli hamuje spontaniczną aktywność i postawy twórcze. Krytykę szkoły wyprowadza z trzech tez:

1) szkoła jako instytucja jest organizmem konserwatywnym i w małym stopniu poddaje się modernizacjom;

2) nauczyciele to na ogół osoby mało twórcze, skrępowane wieloma barierami psychicznymi i psychospołecznymi, hamującymi ich kreatywność;

3) edukacja szkolna wprawdzie przyspiesza rozwój wielu funkcji psychicznych ucznia, jednocześnie staje się jednak źródłem różnorodnych barier psychicznych absolwentów ${ }^{19}$.

Do istotnych wad i niedostatków szkoły można zatem zaliczyć to, iż (por. Dobrołowicz, Pietrasiński, Kozielecki, Palka, Szmidt) formułowanie celów kształcenia służących przystosowaniu uczniów do aktualnych warunków i istniejących struktur społecznych, przekazywaniu gotowej wiedzy. Dziecko rozpoczynające naukę szkolną jest pełne inwencji, ciekawe, a nawet dociekliwe, zadaje oryginalne pytania jednak już krótki pobyt w szkole powoduje osłabienie zainteresowań, i zmianę stosunku do nauki szkolnej. Szkoła niszczy twórcze usposobienie dzieci żądając jedynie recepcji niezliczonych paradygmatów i premiując prawie wyłącznie zachowania konformistyczne. Skupia się na przekazywaniu wiedzy jałowej tzn. wyłącznie oznajmującej i dotyczącej sztucznych sytuacji szkolnych. Jest to wiedza mało implikatywna, nie skłaniająca do for-

${ }^{18}$ E. Nęcka, Psychologia twórczości, Gdańsk 2005.

${ }^{19}$ K. J. Szmidt (red.), Dydaktyka twórczości. Koncepcje - problemy - rozwiazania, Kraków 2005. 
mułowania nowych celów poznawczych, a wymagająca jedynie mechanicznego zapamiętania. Odnosi się tylko do tego, co już wiadomo pomijając zupełnie to, co dopiero warto byłoby odkryć. Szkoły dość łatwo akceptują nowe treści nauczania, znacznie więcej trudności mają natomiast z przyjmowaniem i tworzeniem nowych metod, form, środków dydaktycznych, wciąż dominują metody podające, dominuje transmisyjny i replikacyjny charakter nauczania. Dokonująca się rewolucja naukowo - techniczna w minimalnym stopniu dotknęła instytucje oświatowe. Uczniowie są jedynie przedmiotem oddziaływań, ich inicjatywy, pasje, zainteresowania są spychane na dalszy plan. Bardzo rzadko mają okazję do zadawania oryginalnych pytań i rozwiązywania problemów twórczych, stawiania hipotez i weryfikowania ich, do podejmowania decyzji i ryzykownych programów działania, dominują problemy zamknięte i pytania o niskim poziomie kognitywnym. W toku procesu dydaktycznego nie są rozwijane, a nawet są hamowane twórcze procesy psychiczne: myślenie dywergencyjne, myślenie intuicyjne, wyobraźnia oraz takie cechy osobowości, jak: otwartość, samodzielność i poczucie własnej wartości, premiowane jest myślenie konwergencyjne i odtwórcze. Zaniedbywane jest rozwijanie sfery emocjonalno - motywacyjnej uczniów, dominuje motywacja instrumentalna i zewnętrzna. W szkołach panuje nadmierna rywalizacja, hamująca aktywność eksploracyjną i prowokująca do szukania najprostszego, szybkiego rozwiązania oraz przewaga ocen zewnętrznych. Wśród nauczycieli jest stosunkowo mało osób kreatywnych, nauczyciele nie tylko sami w małym stopniu tworzą, ale też niechętnie przyjmują nowości stworzone przez kogoś innego. Wykazują się słabą orientacją w zdolnościach uczniów, nagradzają poprawne odtwarzanie treści, nie interesują się możliwościami tkwiącymi w dzieciach, nie starają się rozwijać ich potencjału. Wielu posiada autorytarną osobowość, stosuje autokratyczny styl oddziaływania na uczniów, z badań Karolczak - Biernackiej $^{20}$ wynika, iż $60 \%$ nauczycieli szkół podstawowych postawiłoby dobrą ocenę uczniowi mniej zdolnemu, ale zdyscyplinowanemu, usłużnemu, podporządkowującemu się autorytetowi nauczyciela.

Tak mocnej krytyce współczesnej szkoły towarzyszą niezwykle ciekawe próby tworzenia nowych rozwiązań. Psychologowie i pedagodzy wytyczaja pożądany kierunek zmian. Formułują nowe cele i określają sposoby ich osiagania.

Zdaniem J. Kozieleckiego nadrzędnym celem wychowania jest ukształtowanie postawy badawczej człowieka tzn. pewnej trwałej tendencji do poszukiwania problemów w świecie i do samodzielnego ich przezwyciężania. Kształcenie człowieka innowacyjnego, zdolnego nie tyle do przystosowania się do przyszłego świata, ile do tworzenia w nim mądrych innowacji. Człowiek innowacyjny postrzega świat nie jako trwałą i harmonijną strukturę, do której

${ }^{20}$ Za: K. J. Szmidt (red.), Dydaktyka twórczości.... 
łatwo można się przystosować, ale jako zbiór pytań na które trzeba odpowiedzieć, ,jako obszar niepewności poznawczej i praktycznej”. Człowiek innowacyjny działa powodowany pasja poznawcza, stawia sobie pytania, udoskonala układy społeczne i rzeczowe. Postawa badawcza polega na dostrzeganiu i rozwiązywaniu problemów we wszystkich dziedzinach życia ${ }^{21}$. R. Schulz formułuje cztery główne cele kształcenia. Wynikają one z przyjętych w koncepcji kształcenia do innowacji czterech dziedzin twórczości, rozumianych jako zasadnicze kategorie aktywności twórczej ludzi. Są to:

1. Wychowanie do działalności kulturotwórczej. Chodzi w nim o przygotowanie młodzieży do aktywnego uczestnictwa w sferze kultury, do podejmowania działań zmierzajacych do kształtowania ich umiejętności (i gotowości) twórczego, innowacyjnego uczestnictwa w kulturze

2. Wychowanie do twórczej pracy. Zadaniem szkoły jest takie wychowywanie młodego pokolenia, aby było ono $\mathrm{w}$ stanie podjętą $\mathrm{w}$ przyszłości pracę zawodową wykonywać w sposób profesjonalny, twórczy i nowatorski, aby było zdolne do wzbogacania jej o nowe składniki.

3. Wychowanie do zmian społecznych. Podstawowym celem edukacyjnym jest tu kształtowanie twórczych zachowań społecznych. Wychowywanie społecznych innowatorów, czyli ludzi, którzy będą rozwijali nowe wzory zachowań społecznych, którzy będą przekształcali istniejącą rzeczywistość społeczną.

4. Wychowanie do samorozwoju. Zadaniem szkoły jest tu przygotowanie młodzieży do kierowania własnym życiem, pomoc w doskonaleniu się w wybranych dziedzinach, pomoc $\mathrm{w}$ procesie tworzenia własnej osoby ${ }^{22}$.

Proces pobudzania i wspierania twórczości powinien być też oparty na nowych zasadach psychodydaktycznych. Tradycyjne zasady nie pomagają bowiem w realizacji celów kształcenia do twórczości. Podstawowymi zasadami stają się: - zasada podmiotowego traktowania dziecka, czyli tworzenie warunków sprzyjających

- ujawnianiu indywidualnych potrzeb, inicjatyw i pomysłowości, a więc pełnego i bezpiecznego wyrażania siebie,

- zasada nawiązywania do istniejących potrzeb i zainteresowań ucznia oraz budzenia nowych, traktowanie ich jako istotnego motywu realizacji celów psychologicznych, pozwalanie na wybór tematu i charakteru ćwiczeń twórczych,

- zasada ludyczności i stymulowania kształcącej zabawy, poprzez wykorzystywanie naturalnego poczucia humoru dzieci, ich potrzeby zabawy, dzięki którym realizacja nawet trudnych zadań staje się działaniem płynnym i satysfakcjonującym,

${ }^{21}$ J. Kozielecki, Człowiek oświecony czy innowacyjny, [w:] Człowiek wielowymiarowy, pod red. J. Kozielecki, Warszawa 1996.

${ }^{22}$ R. Schulz, Twórczość - Społeczne aspekty zjawiska, Warszawa 1990, s. 358. 
- zasada harmonijnego wpływu na różne sfery osobowości, poprzez pobudzanie procesów poznawczych, emocjonalno - motywacyjnych oraz działań umożliwiajacym dzieciom radzenie sobie w sytuacjach otwartych,

- zasada zachęcania do działań twórczych i pobudzania samodzielności dziecka, to znaczy zachęcanie do podejmowania samodzielnych prób pokonywania trudności i rozwiązywania problemów, zachęcanie do wytrwałości, dawanie poczucia bezpieczeństwa oraz pomoc $\mathrm{w}$ pokonywaniu nieśmiałości, lęku przed nieznanym $\mathrm{i}$ innych barier napotykanych w działaniach twórczych,

- zasada stosowania bogatych i zróżnicowanych środków dydaktycznych, wzbudzających ciekawość, stymulujących percepcję, myślenie racjonalne, intuicję i wyobraźnię poprzez zachęcanie do manipulowania nimi oraz inspirowanie do samodzielnego tworzenia nowych środków,

- zasada budowania i kultywowania klimatu bezpieczeństwa i życzliwości, wychowawca podejmuje określone działania sprzyjające powstawaniu i utrwalaniu się atmosfery zaufania, życzliwości, nieskrępowanego dzielenia się pomysłami, odważnego poszukiwania niebanalnych rozwiązań i puszczania wodzy fantazji,

- zasada ciagłego podsycania i utrzymywania ciekawości poznawczej ucznia, poprzez wzbudzanie stanu zaciekawienia różnymi problemami, wyrażanie aprobaty dla pytań stawianych przez dziecko, zachęcanie do odkrywania nowych problemów oraz do kwestionowania ustalonych porządków i prawd, pozostawianie niektórych pytań bez odpowiedzi, aby prowokować do myślenia, ukazywanie niekompletność istniejącej wiedzy przez ujawnianie tajemnic i nierozwiązanych problemów,

- zasada wzmacniania procesu twórczego i tolerowania błędów, główny akcent pada na doświadczenia i przeżycia dziecka uczącego się nowych zachowań i umiejętnosci, a nie na efekt, wytwór procesu twórczego.

- zasada oceniania wytworów i zachowań poprzez opis i opinie, a więc rezygnację $\mathrm{z}$ tradycyjnej oceny cyfrowej na rzecz oceny opisowej $\mathrm{i}$ informacji zwrotnej, która umożliwi dziecku zrozumienie własnych błędów i niedostatków oraz pozwoli je naprawić lub zminimalizować ${ }^{23}$.

E. Nęcka wskazując na wagę ciekawości poznawczej formułuje pięć zasad dzięki, którym jest ona stymulowana:

Nie bój się pytań - aktywność twórcza rozwija się jedynie w atmosferze, w której o wszystko można zapytać, wszystko można zakwestionować, o wszystkim można dyskutować. Dlatego zadawanie pytań jest rodzajem zachowania, które należy wzmacniać. Nie jest ważne jak i o co dziecko pyta, ale że w ogóle pyta. Stawianie pytań jest przejawem aktywności potencjalnie twórczej, czyli

${ }^{23}$ K. J. Szmidt, J. Bonar, Program edukacyjny Żywioty. Lekcje twórczości w nauczaniu zintegrowanym, Warszawa 1998. 
takiej, która może w konsekwencji doprowadzić do nowego spojrzenia na świat lub przynajmniej fragment rzeczywistości.

Stawiaj pytania otwarte - stawiając pytania otwarte uzyskujemy wartościowy efekt $w$ postaci zwiększenia produktywności myślenia. Stymulujemy też ciekawość poznawczą, ponieważ często dopiero po przekształceniu pytania zamkniętego $\mathrm{w}$ otwarte dostrzegamy całe bogactwo wiedzy możliwej do wykorzystania w trakcie szukania odpowiedzi na pytanie otwarte.

Nie odpowiadaj na niektóre ważne pytania - niekiedy istotne pytania powinny przez jakiś czas pozostać bez odpowiedzi, ponieważ w ten sposób prowokują do myślenia. Sytuacje niedomknięte, niedopowiedziane zapadają w pamięć i pobudzają emocjonalnie stąd mogą sprowokować spontaniczną aktywność intelektualną. Przerwy w myśleniu mogą przeradzać się w okresy „inkubacji” czyli nie do końca uświadomionego produkowania nowych pomysłów podczas snu, odpoczynku czy aktywności sportowej.

Ukazuj niekompletność istniejacej wiedzy - wiedza przekazywana w szkole często sprawia wrażenie skończonej, w której niewiele może ulec zmianie. Rzeczywistość jest jednak zupełnie inna. W prawdziwej wiedzy naukowej pełno jest luk, niejasności, sprzecznych danych i niedokładnych interpretacji. Jeśli jednak młodzi ludzi poznają świat poprzez pryzmat skończonych teorii i dobrze utrwalonych poglądów mogą odnieść wrażenie, że w nauce nie ma już nic do zrobienia.

Ukazuj trendy w rozwoju wiedzy - w toku edukacji powinniśmy uświadamiać uczniom, że wiedza ludzka znajduje się w toku nieustannego rozwoju. To, co wiemy teraz jest zwykle efektem długotrwałego procesu rozwojowego. Jeśli tak, to nasza obecna wiedza może być traktowana jako punkt wyjścia do przyszłej, jeszcze nieznanej wiedzy. Skoro wszystko się rozwija, nie ma powodu, aby obecną rzeczywistość traktować jako zastygłą w bezruchu. Taki punkt widzenia sprzyja stymulowaniu ciekawości poznawczej ponieważ zachęca do stawiania pytań o kierunek zmian, tempo ewolucji oraz punkt, do którego te zmiany prowadzą ${ }^{24}$.

\section{Postawy nauczyciela, czyli czy potrafimy pomagać w tworzeniu}

W rozwijaniu twórczości potrzebne są nie tylko nowe cele i nowe sposoby ich realizacji, ale także nowa atmosfera wychowawcza. Shaw i Cliatt piszą o potrzebie tworzenia atmosfery ciepła i zaufania, czasem także swobody i wesołości ${ }^{25}$. Zdaniem Jana Zborowskiego stwarzanie atmosfery sprzyjającej

${ }^{24}$ E. Nęcka, Stymulowanie ciekawości, „Carpe Diem” 1998, nr 1.

${ }^{25}$ Za I. Labuda, Twórczy nauczyciel w oczach uczniów, [w:] Kreatywność - nowe aspekty poznawcze i praktyczne, pod red. W Dobrołowicz, J. Gralewski, Warszawa 2005. 
twórczości polega na zachęcaniu dziecka do tworzenia, na umiejętnym kierowaniu procesem twórczym bez ograniczania inicjatywy oraz bez narzucania uniformistycznych sposobów zachowania ograniczających rozwój dziecka i prowadzących do zagubienia przez nie tożsamości ${ }^{26}$. Praca nauczyciela nastawiona na kształtowanie myślenia twórczego, a także działania oryginalne i twórcze może spowodować, że twórczych zachowań ze strony uczniów będzie więcej i że będą one bardziej wartościowe ${ }^{27}$. Wśród postulatów kierowanych pod adresem wychowawców (por. T. Amabile, B. Hennessey, E. P. Torrance), najczęściej pojawiają się następujące:

1. Pamiętaj, że dziecko będzie bardziej twórcze, jeśli będzie cieszyć się tym, co robi.

2. Dostarczaj dziecku wielu okazji do swobodnej zabawy różnymi materiałami i pozwól angażować $\mathrm{w}$ to fantazję. Uwrażliwiaj na bodźce istniejące w otoczeniu.

3. Zachęcaj dziecko, by było aktywne, niezależne, uczące się i bardziej samodzielne w podejmowaniu decyzji zamiast polegania na twoich ciagłych wskazówkach. Zachęcaj do ufnej kontroli własnego procesu uczenia się. Dawaj dziecku możliwość wyboru rodzaju i sposobu działania, tak często, jak tylko jest to możliwe. Zachęcaj do testowania nowych pomysłów, do podejmowania ryzyka, do przemyśleń nad poleceniami. Zapewniaj dziecku zarówno okresy wzmożonej aktywności jak i względnego spokoju.

4. Zabijaj ćwieka dziecku. Warunkiem twórczości jest dziwienie się. Osoby dla których wszystko jest jasne, zrozumiałe, oczywiste, raz na zawsze rozwiązane, nie myślą twórczo.

5. Dyskutuj z dzieckiem na temat jego wewnętrznej motywacji poznawczej, pomóż mu uświadomić sobie jego zdolności, talenty, zainteresowania i odwróć uwagę od warunkujących je czynników zewnętrznych. W każdy możliwy sposób pokazuj dziecku, że cenisz jego twórczość, że jesteś elastyczny, wszechstronny i zainteresowany twórczymi dokonaniami.

6. Zachęcaj dziecko bardziej do kontrolowania własnej pracy, niż do polegania na twoich obserwacjach. Umniejszaj znaczenie oceny zewnętrznej. Używaj nagród rzeczowych tak rzadko, jak to możliwe; w zamian zachęcaj do odczuwania dumy z dobrze wykonanej pracy.

7. Bądź cierpliwy - twórcze efekty pracy dziecka każą na siebie czekać, a klimat oczekiwania na natychmiastową odpowiedź blokuje myślenie twórcze ${ }^{28}$.

Kolejnym ważnym obszarem wiedzy pozwalającym na podnoszenie efektywności oddziaływań edukacyjnych poprzez rozwijanie twórczości są zagad-

${ }^{26}$ J. Zborowski, Rozwijanie aktywności twórczej dzieci, Warszawa 1986.

${ }^{27}$ Por. M. Karwowski (red.), Identyfikacja potencjału twórczego. Teoria. Metodologia. Diagnostyka, Warszawa 2009.

${ }^{28}$ Za: K. J. Szmidt (red.), Dydaktyka twórczości... 
nienia związane z postawą twórczą. Pojawiają się tu pytania o to, jakie cechy charakteryzują twórców i jakie w związku tym cechy powinniśmy wspierać i rozwijać u naszych wychowanków. Garry A. Davis podjął próbę uporządkowania ponad 200 cech, za pomocą których opisuje się osobowość twórczą. Cechy te podzielił na pozytywne i negatywne. Do pozytywnych cech zaliczył: świadomość twórczości, oryginalność, niezależność i chęć podejmowania ryzyka, wysoką energię, dokładność, ciekawość, poczucie humoru, zamiłowanie do fantazjowania, złożoności i nowości, zainteresowania artystyczne i estetyczne, otwartość umysłu, potrzebę samotności, spostrzegawczość i wrażliwość zmysłowa, emocjonalność, etyczność (empatia, idealizm, altruizm) ${ }^{29}$. R. Fisher wskazuje, iż w każdym z nas toczy się spór pomiędzy „, ja - ostrożnym” (nie robiłbym tego ... to zbyt ryzykowne...), a „, ja - badawczym"(a spróbujmy to tak..., zaryzykujmy...). Ja ostrożne - podejrzliwe wobec nowości, powściagliwe, przywiązane do znanych dróg, chętnie przestrzega reguł, konwencjonalne, polega na innych, karze za błędy, unika ryzyka, wietrzy niebezpieczeństwo, unika pomyłek, lęka się konsekwencji, zachowuje powagę, unika niespodzianek, chce mieć pewność, nie uzewnętrznia uczuć. Ja badawcze - otwarte na nowe doświadczenia , ciekawskie, lubi domysły, ceni intuicję jest niekonwencjonalne, wykazuje niezależność, nie martwi się kiedy nie ma racji, podejmuje ryzyko, poszukuje nowych dróg, czyni obiecujące skojarzenia, lubi grę, szuka zabawnej strony, lubi zaskoczenia, posługuje się wyobraźnią, dzieli się marzeniami. Najlepiej jest, gdy obie strony współwystępują, współpracują. Szczególnie łatwo jest jednak unicestwić już w dzieciństwie śmiałe, skłonne do ekspresji i eksperymentowania ,ja, 30 .

Również Krystyna Bieluga wskazuje, odwołując się do literatury oraz wykorzystując własne obserwacje, zachowania świadczące o wysokim poziomie myślenia twórczego uczniów. Należą do nich:

* posiadanie oryginalnych pomysłów; konstruowanie własnych oryginalnych pomysłów, przetwarzanie i dostosowywanie do danej sytuacji pomysłów innych;

* formułowanie niecodziennych pytań, problemów; stawianie wielu pytań, zwłaszcza oryginalnych, rzadko spotykanych, dotyczących różnych aspektów życia, świadczących o szerokich zainteresowaniach;

* dostrzeganie w znanych sytuacjach nowych problemów wartych rozwiązania; zdolność do spojrzenia z innej perspektywy na codzienne sprawy, bycie , niespokojnym duchem", który wszystko chce budować na nowo, zgłaszanie pomysłów doskonalących otoczenie;

${ }^{29}$ Za: K. J. Szmidt, K. Piotrowski (red.), Nowe teorie twórczości. Nowe metody pomocy w tworzeniu, Kraków 2002.

${ }^{30} \mathrm{R}$. Fischer, Uczymy jak myśleć... 
* chodzenie własnymi drogami; zdolność do tworzenia własnego stylu życia; u dzieci przejawia się własnymi wyobrażeniami o tym, co chcą robić i w jaki sposób; często prowadzi do konfliktów z dorosłymi, których oczekiwania i oceny mogą być inne ${ }^{31}$.

Powszechnie wiadomo jednak, że nauczyciele nie lubią uczniów zbyt twórczych. Wolą tych, którzy są dobrze przygotowani do zajęć oraz zachowują się zgodnie $\mathrm{z}$ oczekiwaniami. Dzieci twórcze mają wśród nauczycieli opinię niegrzecznych, sprawiających kłopoty, niepodporządkowujących się dyscyplinie szkolnej. Potwierdzają to wyniki badań (Getzels i Jakson, 1962; Torrance, 1965; Wallach i Kogan, 1965) przytaczane przez Edwarda Nęckę. Jego zdaniem może tak być w rzeczywistości, ponieważ dzieci twórcze charakteryzuje podatność na rozproszenie uwagi, przez co są one mniej zdolne do uważania na lekcjach, a bardziej skłonne do podejmowania aktywności niezgodnej z oczekiwaniami nauczycieli. Istnieje potwierdzona w badaniach zależność między kreatywnością, a częstością kierowania ucznia na dyscyplinujące rozmowy z dyrektorem szkoły $^{32}$. Nauczyciele moga więc mieć rzeczywiste podstawy do tego, aby uważać twórczych uczniów za niezdyscyplinowanych i kłopotliwych. Również Maciej Karwowski zauważa, że twórczy uczniowie stawiają nauczycieli wobec licznych trudności i podaje przykładowe problemy. Są nimi: zagrożenie dyscypliny, nieoczekiwane odpowiedzi, kłopotliwe pytania, kary za zgadywanie oraz skłonność do żartów. Zagrożenie dyscypliny może być spowodowane rozbieżnym myśleniem dziecka twórczego, które przerywa tok lekcji i przez to jest postrzegane jako nieposłuszne. Jego postawa może prowokować także innych uczniów, którzy wykorzystają okazję do przeszkadzania i celowego i złośliwego zakłócenia toku zajęć. Twórczy uczniowie mają również łatwość w wymyślaniu nieoczekiwanych rozwiązań i tworzeniu niezwykłych odpowiedzi, jeśli nauczyciel postawi pytanie wymagające uruchomienia twórczej wyobraźni. Tego typu odpowiedzi zakłócają dokładnie zaplanowaną lekcję i mogą być postrzeganie jako próba ośmieszenia osoby nauczyciela. Podobne problemy stwarzaja kłopotliwe pytania zadawane nauczycielowi przez twórczych uczniów, ponieważ dostrzegają oni często związki niezupełnie dla nauczycieli oczywiste. Twórczy uczniowie przejawiają także skłonność i gotowość do domyślania się i zgadywania. Tymczasem $\mathrm{w}$ naszym systemie szkolnym zgadywanie jest postrzegane przez nauczycieli jako nielogiczny sposób rozwiązywania problemu, który w niewielkim stopniu prowadzi do poprawnego rozwiązania. Nauczyciel powinien jednak odróżniać bezmyślne zgadywanie, nie oparte na wiedzy, od

${ }^{31} \mathrm{~K}$. Bieluga, Nauczycielskie rozpoznawanie cech inteligencji i myślenia twórczego, Kraków 2003.

${ }^{32}$ E. Nęcka, Psychologia twórczości, Gdańsk 2005. 
odważnych, pomysłowych przypuszczeń, które mogą skrócić długi proces rozumowania i doprowadzić do całkiem nowych, nieznanych dotąd rozwiązań ${ }^{33}$.

Taka sytuacja i opinia nauczycieli ma olbrzymie konsekwencje, ponieważ wpływa na sposób traktowania ucznia oraz na ocenę jego wytworów.

W celu zweryfikowania tych poglądów i poznania rzeczywistych oczekiwań nauczycieli wobec uczniów przeprowadziłam badania, których celem było nakreślenie obrazu ucznia idealnego. Badania przeprowadzono wśród 145 nauczycieli wczesnej edukacji pracujących w Łodzi. Wykorzystano w nich kwestionariusz opracowany przez Renatę Wiechnik, a zawierający 61 cech: uprzejmy, spostrzegawczy, uczynny, ciekawy, pracowity, punktualny, z poczuciem humoru, posłuszny, systematyczny, pomysłowy, sumienny, dociekliwy, ambitny, aktywny, zadający nietypowe pytania, koleżeński, cierpliwy, o wszechstronnych zainteresowaniach, zdyscyplinowany, nominatywny, odważny, o dobrej pamięci, obowiązkowy, odpowiedzialny, o bogatej wyobraźni, życzliwy, prawdomówny, o dużej inteligencji, opanowany, oryginalny, o wysokiej kulturze osobistej, samodzielny w rozwiązywaniu problemów, bystry, samokrytyczny, niezależny w myśleniu, dokładny, pilny, wrażliwy, spontaniczny, pewny siebie, tolerancyjny, przejawiający upór w rozwiązywaniu interesujących go problemów, odnoszący sukcesy $\mathrm{w}$ nauce, uzdolniony, udzielający się społecznie, energiczny, uczciwy, elokwentny, schludny, swobodny, śmiały, przejawiający wysoką motywację do nauki szkolnej, przejawiający giętkość i plastyczność myślenia, prospołeczny, wytrwały, skromny, oczytany, stawiający wiele pytań, nonkonformistyczny, kochający przyrodę, wykazujący troskę o wspólną własność. Nauczyciele wybierali 10 spośród wszystkich podanych cech i przypisywali im wartość od 1 do 10. Najwyżej ocenione zostały następujące cechy:

1. Pracowity $-4,79$

2. Systematyczny $-3,15$

3. Ambitny $-2,96$

4. Obowiazkowy $-2,67$

5. Sumienny $-2,26$

6. Zdyscyplinowany $-2,33$

7. Przejawiający wysoką motywację do nauki szkolnej - 1,98

8. Aktywny $-1,87$

9. Koleżeński - 1,84

10. O wysokiej kulturze osobistej - 1,70

Przedstawiona lista cech została również wykorzystana do poznania opinii badanych nauczycieli na temat ucznia twórczego. Nauczyciele wybierali 10

${ }^{33}$ M. Karwowski, R. Ciak, M. Grubek, Patrzy, ale czy widzi? Trafność nominacji nauczycielskich w rozpoznaniu kreatywności uczniów, [w:] Identyfikacja potencjału twórczego. Teoria. Metodologia. Diagnostyka, pod red. M. Karwowski, Warszawa 2009. 
cech, które ich zdaniem charakteryzują ucznia twórczego. Tym razem najwyżej oszacowane zostały następujące cechy:

1. Pomysłowy $-5,78$

2. O bogatej wyobraźni $-5,34$

3. Przejawiający giętkość i plastyczność myślenia - 4,38

4. Oryginalny $-3,00$

5. Niezależny w myśleniu $-2,76$

6. Dociekliwy $-2,68$

7. Samodzielny w rozwiązywaniu problemów $-2,51$

8. Aktywny $-2,18$

9. Zadający nietypowe pytania $-2,05$

10. Spostrzegawczy $-2,02$

Analiza tej listy wskazuje, iż nauczyciele dość dobrze rozpoznają cechy świadczące o kreatywności jednostki. (Prawdziwy zatem wydaje się pogląd Macieja Karwowskiego, iż dostrzeżenie twórczego ucznia w klasie szkolnej nie wymaga od nauczycieli wiedzy z zakresu psychologii twórczości czy diagnozy pedagogicznej, wystarczy wrażliwość i rodzaj pasji intelektualnej ${ }^{34}$ ). Niestety nie doceniają ich roli. W obrazie ucznia idealnego znalazła się tylko jedna cecha spośród tych, które zdaniem badanych nauczycieli świadczą o postawie twórczej ucznia. Wydaje się, iż jest to dowód świadczący o niedocenianiu postawy twórczej wychowanków. Jeśli zatem nauczyciele nie cenią takich cech to można również przypuszczać, iż nie wspierają ich w procesie dydaktycznym.

Na zakończenie przytoczę postulaty samych uczniów i ich oczekiwania wobec twórczego nauczyciela. Wydaje się, że powinni je znać nie tylko nauczyciele pracujący w szkołach, ale także rodzice podejmujący trudne zadanie wspierania edukacji domowej własnych dzieci. Wyniki badań prowadzonych przez I. Labudę w klasach na poziomie kształcenia zintegrowanego pokazują, że zdaniem najmłodszych wychowanków twórczy nauczyciel jest osobą mądrą, z dużym poczuciem humoru i rozwiniętą wyobraźnią. Słucha swoich uczniów i widzi ich potrzeby, nie boi się nowoczesnych rozwiązań techniki, jest odważny. Przede wszystkim zaś lubi swoich uczniów ${ }^{35}$.

Wydaje się, że cechy te pomagają w zrozumieniu i akceptacji uczniowskiej twórczości. To ważne ponieważ daniem Carliny Rinaldi kreatywność musi być aprobowana, aby mogła stać się wspólnym dziełem. Zbyt często jednak boimy się kreatywności , nawet naszej własnej, ponieważ sprawia one, że jesteśmy „inni”. Kreatywność wymaga kontekstu, który pozwala jej istnieć i być wyrażaną, pozwala jej stać się widoczną. W szkole kreatywność powinna mieć możliwość bycia wyrażaną w każdym miejscu i w każdym momencie. Szkoła powin-

\footnotetext{
${ }^{34}$ M. Karwowski (red.), Identyfikacja...

${ }^{35}$ I. Labuda, Twórczy...
} 
na być miejscem kreatywnego uczenia się i kreatywnych nauczycieli, a nie tylko „godziny kreatywności”. Nie ma kreatywności w dziecku jeśli nie ma kreatywności w dorosłym. Kompetentne i kreatywne dziecko istnieje jeśli obok niego jest kompetentny i kreatywny dorosły ${ }^{36}$.

JOLANTA BONAR

\section{Recognising and encouraging pupil's creativity as a task for an early education teachers}

A basic idea of the author is to indicate that recognising and encouraging pupil's creativity is one of the main tasks of modern school. It thereby requires teachers to have an appropriate knowledge, regardless the level they are working on. Enormously important are first years of an education. On them mostly depends who in a sense of personality and intellect the students are going to be, what thinking strategies they will have developed and which, maybe even most importantly, they will be deprived of.

${ }^{36}$ C. Rinaldi, Creativity as a quality of thought, [w:] In Dialogue with Reggio Emilia: listening, researching and learning. London: Routledge 2006. 